\title{
CSF SERPINA3 Levels Are Elevated in Patients With Progressive MS
}

Neurol Neuroimmunol Neuroinflamm 2021;8:e983. doi:10.1212/NXI.0000000000000983

In the article "CSF SERPINA3 Levels Are Elevated in Patients With Progressive MS" by N. Fissolo et al., ${ }^{1}$ Dr. Nicolás Fissolo should be listed as a corresponding author in addition to Dr. Manuel Comabella Lopez. Dr. Fissolo can be reached at nicolas.fissolo@vhir.org. The authors and editorial staff regret the omission.

\section{Reference}

1. Fissolo N, Matute-Blanch C, Osman M, et al. CSF SERPINA3 levels are elevated in patients with progressive MS. Neurol Neuroimmunol Neuroinflamm 2021;8:e941. doi: 10.1212/NXI.0000000000000941. 


\title{
Neurology \\ Neuroimmunology \& Neuroinflammation
}

\author{
CSF SERPINA3 Levels Are Elevated in Patients With Progressive MS \\ Neurol Neuroimmunol Neuroinflamm 2021;8; \\ DOI 10.1212/NXI.0000000000000983
}

This information is current as of March 1, 2021

\section{Updated Information \& \\ Services}

References

Permissions \& Licensing

Reprints including high resolution figures, can be found at:

http://nn.neurology.org/content/8/3/e983.full.html

This article cites 1 articles, 1 of which you can access for free at: http://nn.neurology.org/content/8/3/e983.full.html\#\#ref-list-1

Information about reproducing this article in parts (figures,tables) or in its entirety can be found online at:

http://nn.neurology.org/misc/about.xhtml\#permissions

Information about ordering reprints can be found online: http://nn.neurology.org/misc/addir.xhtml\#reprintsus

Neurol Neuroimmunol Neuroinflamm is an official journal of the American Academy of Neurology.

Published since April 2014, it is an open-access, online-only, continuous publication journal. Copyright $(\subseteq$ 2021 American Academy of Neurology. All rights reserved. Online ISSN: 2332-7812.

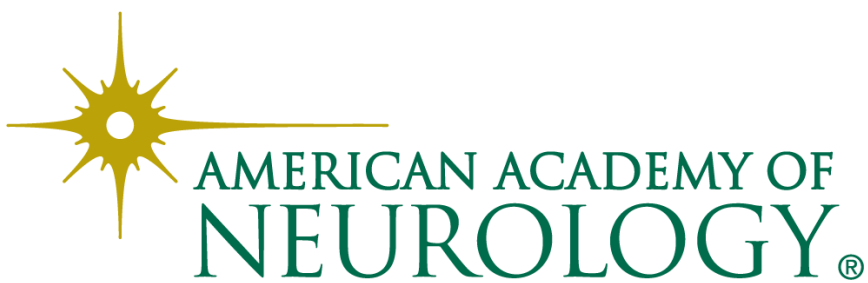

